\title{
Communication
}

[Comunicação]

\section{Gross and histopathological findings in magellanic penguins (Spheniscus magellanicus Forster, 1781)}

[Achados necroscópicos e histopatológicos em pinguins-de-Magalhães

(Spheniscus magellanicus Forster, 1781)]

C.O. Carvalho ${ }^{1}$, S.C. Cuenca ${ }^{1}$, S.R. Kleeb ${ }^{1}$, H. Gallo ${ }^{2}$, P. Baldassin ${ }^{3 *}$

${ }^{1}$ Universidade Metodista de São Paulo - SP

${ }^{2}$ Aquário de Ubatuba - Ubatuba, SP

${ }^{3}$ Instituto Argonauta para a Conservação Costeira e Marinha - Ubatuba, SP

Magellanic Penguins, Spheniscus magellanicus Forter, 1781, are bred mainly along the coasts of Chile and Argentina (Bingham, 2002). After the breeding season (September to March), adults and juveniles leave their colonies and migrate north, accompanying the movement of ocean currents, such as the Falkland current (Sick, 1997). During these movements Magellanic Penguins reach the waters off the Brazilian coast, especially off states in southern Brazil as far north as Rio de Janeiro. Occasionally specimens can be found as far north as the state of Bahia (Roos, 2008). Although they do not breed in Brazil, juveniles are found alive and dead along the Brazilian coast outside the breeding season, during the fall and winter (Boersma, 2008; Garcia-Borboroglu et al., 2010). This has been happening for many years as shown from archeological remains (Gaspar, 1999)

A number of hypotheses have arisen regarding the increase in the appearance of juvenile Magellanic penguins in the southern and southeastern regions of Brazil. It is believed that these birds may undergo innumerous situations of stress during migration, such as abrupt climate variations, food deprivation, parasite infestation, physical harm, human action, pollution, predation and disease (Garcia-Borborglu et al., 2010). Many individuals arrive on Brazilian beaches dehydrated and hypothermic, with traumatic injuries or covered in oil, requiring care at rehabilitation centers (Xavier et al., 2007, Garcia-Borborglu et al., 2010).

Recebido em 18 de novembro de 2011

Aceito em 31 de janeiro de 2012

* Autor para correspondência (corresponding author)

E-mail: paulets@usp.br
Juvenile Magellanic penguins $(n=24)$ that died at CRETA (Ubatuba Aquarium/Argonaut Institute, Brazil), a rehabilitation center in Ubatuba, São Paulo, Brazil, in 2008, were found on the northern coast of the state of São Paulo and the southern coast of the state of Rio de Janeiro. Upon initial examination, the individuals were cachectic, unable to stand erect and to maintain the body temperature which was $33^{\circ} \mathrm{C}$ or less, exhibited debilitation, dehydration, bradycardia and lethargy, the respiratory rate was lower than normal and subsequently they died within hours or a few days.

During necropsy, histological samples were collected from lung, liver and kidney. Other tissues were not examined. They were fixed in $10 \%$ formalin, following the procedures described by Hocken (2002). Representative lesions were examined in 21 of the 24 penguins necropsied. Gastrointestinal lesions were found in all 21 specimens, among which intestinal parasitosis was the most frequent condition (found in $66.7 \%$ of the specimens), followed by the presence of a foreign body in the stomach (19.04\%) and intestinal vascular lesions (14.3\%), such as hemorrhage and congestion.

Hepatic vascular lesions and vascular lesions in air sacs and lungs, such as congestion and cardio-hepatomegaly were found in $29.2 \%$. Heart and pancreas lesions, such as congestion and hemorrhage were found in $12.5 \%$. Only $4.2 \%$ exhibited pale brown kidney coelomitis. There were no gross important lesions identified in three specimens. Table 1 displays the anatomopathological lesions in the sample. 
Table 1. Anatomopathological lesions in Magellanic penguins from Ubatuba Aquarium/Argonauta Institute necropsied between July and December 2008

\begin{tabular}{lc} 
Anatomopathological lesions & $\begin{array}{c}\text { Registry number of affected } \\
\text { animals }\end{array}$ \\
\hline Poor body condition & 20 \\
Liver lesions & 7 \\
Intestine lesions & 3 \\
Respiratory tracts lesions & 7 \\
Presence of trash in stomach & 4 \\
Presence of parasites in gastrointestinal tract & 14 \\
Pancreas lesions & 3 \\
Heart lesions & 3 \\
Kidney lesions & 1 \\
Adherence of organs in body cavity (coelomitis) & 1 \\
\hline
\end{tabular}

Poor body condition, characterized by cachexia, with a reduction in muscle mass and scant adiposus tissue, was a frequent finding, occurring in $83.3 \%$ of the specimens.

Among the 24 penguins assessed histologically, four were in an advanced state of autolysis, which hindered the identification of histopathological lesions. Therefore, only 20 penguins underwent this analysis. Only one specimen exhibited no important microscopic lesions. Table 2 displays these findings.

Table 2. Microscopic lesions in Magellanic penguins from Ubatuba Aquarium/Argonauta Institute necropsied between July and December 2008

\begin{tabular}{lc}
\hline Microscopic lesions & $\begin{array}{c}\text { Registry number } \\
\text { of affected } \\
\text { animals }\end{array}$ \\
\hline Hepatic congestion & 10 \\
Hepatitis & 08 \\
Pulmonary hemorrhage & 06 \\
Pulmonary congestion & 15 \\
Pulmonary inflammation & 02 \\
Nephrosis & 01 \\
Splenitis & 01 \\
\hline
\end{tabular}

Lung congestion was the most frequent histopathological lesion, occurring in $75 \%$ of the cases and characterized by dilatation of circulation, pulmonary microcirculation and the filling of the vascular bed with red subtle blood cells and consequent thickening of the wall of the parabronchi. Among these specimens, 40\% exhibited hemorrhage, in which red blood cells were identified outside the vascular territory. In some cases, there was buildup of acidophilic material in the lumen of the parabronchi, characterizing pulmonary edema. In two specimens associated to previous lesions, subtle inflammatory infiltration was observed, with no identification of the etiological agent.

Another important histopathological finding was passive hepatic congestion, found in $50 \%$ of the specimens. These cases exhibited sinusoidal dilatation, cordonal disarrangement and buildup of red blood cells in the vascular bed. In the periacinal region or surrounding the terminal hepatic vein, subtle necrosis of hepatocytes was identified and, in many cases $(80 \%)$, there was mononucleated leukocyte infiltration, characterizing subtle hepatitis in the periacinal region.

Nephrosis was identified in one of the specimens, which was visualized by the detachment of the tubule epithelium and buildup of intra-tubule protein material. In the remaining specimens, the kidney was either preserved or exhibited subtle vacuole degeneration. Diffuse mononucleated leukocyte infiltration was found in one of the specimens, confirming splenitis.

For the adequate characterization of lesions in animals that die during migration, Keymer et al. (2001) reports that standardized, systematic necropsy is needed. Moreover, complementary exams should be carried out, such as microbiological and toxicological analyses, in order to establish a more precise diagnosis of the illnesses that affects penguins. In the present study, $83.3 \%$ of the specimens exhibited poor body conditions, which may have been an important primary or secondary factor in the cause of death (Hocken, 2002). 
Unlike what Xavier et al. (2007) suggests, infectious disease did not constitute a significant factor in the cause of death of the animals examined in the present study, tracheal swab was made on animals that come in alive and no pathogen presence was detected.

Few specimens exhibited indications of important bacterial, viral or fungal infection. In a study carried out by Fowler (2001), the author reports that some animals likely had insufficient exposure time to pathogens and died as a result of some other primary cause developed prior to becoming infected.

According to Cappua et al. (2007), parasitosis may be a contributing factor to the death of penguins that arrive debilitated to beaches. The study of helminthes in specimens of S. magellanicus from Ubatuba, São Paulo demonstrated a high prevalence of infection by Contracaecum. pelagicum and Cardiocephaloides physalis, with lesser mean intensity and abundance of infection in comparison to breeding grounds in Patagonia, Argentina (Díaz et al.,2010)

Lumeij (1994) describes congestive heart failure as a clinical syndrome that can be defined as the compensated condition associated with fluid retention that result from a sustained inadequacy of the cardiac output to meet the demands of the body. Severe anorexia may result in the loss of muscle mass and according to Rome (2003), this includes the heart, in which muscle gets weak and the blood pressure drops, resulting in slower breathing and heartbeat rates. In humans the main death cause in anorexic/cachectic people is the heart failure that results in a wasted cardiac muscle, sinus bradycardia, hypotension, reduced left ventricular mass, associated with systolic dysfunction (Rome, 2003) and abnormalities of mitral valve motion (De Simone, 1994). The most frequent anatomopathological findings in this work were related to vascular lesions in the lungs and liver, such as pulmonary hypertension and passive hepatic congestion. These lesions are found in birds experiencing a metabolic overload associated to environmental adversity (Jaenisch et al., 2005).

Furthermore, hypothermia should also be considered, since these birds have high metabolic body rates to maintain. According to Lipscomb (1993) death caused by hypothermia can occur without distinctive gross or microscopic lesions.

According to Fowler et al. (2001), heptatis encountered in the microscopic analysis with characteristics of a toxic origin may be related to the buildup of heavy metals, pesticides in the fish consumed, disinfectants and diverse pollutants found in the environment. According to Boersma (2008), penguins are sentinels of the marine environment, through which scientists can learn about the rates and nature of changes that occur in the South Atlantic. Penguins face changes in the environment, whether climatic changes or negative factors stemming from human activities. According to Pütz et al. (2007), Magellanic penguins are increasingly threatened by human activities in coastal areas along their migration path. Although penguins demonstrate adaptations to the variability in the environment, environmental disturbances constitute a threat to their population.

The characterization of the death of penguins that arrive at Brazilian beaches is extremely important for the determination of morbid processes and the establishment of therapeutic and management strategies directed at surviving penguins.

Keywords: Magellanic penguin, gross, histopathology

\section{RESUMO}

Durante os movimentos migratórios os Pinguins-de-Magalhães chegam às águas da costa brasileira, especialmente nos estados do sul do Brasil até o estado do Rio de Janeiro. Muitos chegam desidratados, hipotérmicos, com lesões traumáticas ou coberto de óleo, exigindo cuidados especiais em centros de reabilitação. Vinte e quatro pinguins juvenis, que chegaram para a reabilitação e posteriormente vieram a óbito apresentaram caquexia, incapacidade de ficar ereto e manter a temperatura do corpo, média de $33^{\circ} \mathrm{C}$ ou menos, apresentando desidratação, bradicardia e letargia. Durante a necrópsia, amostras histológicas foram coletadas de fígado, pulmão e rim. Um importante achado histopatológico foi a congestão hepática passiva, encontrada em 50\% dos espécimes e a congestão pulmonar foi a lesão 
histopatológico mais frequente, ocorrendo em $75 \%$ dos casos. Anorexia pode acarretar a perda de massa muscular e isso inclui o coração, fazendo com que ocorra uma diminuição da pressão cardíaca, resultando em uma respiração mais lenta e uma bradicardia. Os principais achados anatomopatológicos neste trabalho foram relacionados a lesões vasculares nos pulmões e no fígado, sendo estes encontrados em aves que experimentam uma sobrecarga metabólica associada à adversidade ambiental.

Palavras-chave: pinguim-de-Magalhães, necrópsia, histopatologia

\section{REFERENCES}

BINGHAM, M. The decline of Falkland Islands penguins in the presence of a commercial fishing industry. Rev. Chil. Hist. Nat., v.75, p.805-818, 2002.

BOERSMA, P.D. Penguins as Marine Sentinels. BioScience, v.58, p.597-607, 2008.

CAPPUA, G.A.; BASSI, P.B.; ADORNES, A.C. et al. Ocorrência de Contracecum pelagicum em esôfago e estômago de Spheniscus magellanicus. In: XVI CONGRESSO DE INICIAÇÃO CIENTÍFICA, Faculdade de Agronomia Eliseu Maciel. Anais... Pelotas, 2007. (Resumo)

DE SIMONE, G.; SCALFI, L.; GALDERISI, M. et al. Cardiac abnormalities in young women with anorexia nervosa. Br. Heart J., v.71, p.287292, 1994.

DÍAZ, J.I.; CREMONTE, F.; NAVONE, G.T. Helminths of the Magellanic penguin, Spheniscus magellanicus (Sphenisciformes), during the breeding season in Patagonian coast, Chubut, Argentina. Comp. Parasitol., v.77, p.172-177, 2010.

FOWLER, G.S.; FOWLER, M.E. Order Sphenisciformes (Penguins). In FOWLER, M.E.; CUBAS, Z.S. Biology, medicine and surgery of South American wild animals. 1st Ed. 2001. p.53-64.

GASPAR, M.D. Sambaqui: arqueologia do litoral brasileiro. Rio de Janeiro: Jorge Zahar Editor, 1999. 89p.

GARCÍA-BORBOROGLU, P.; BOERSMA, P.D.; RUOPPOLO, V. et al. Magellanic penguin mortality in 2008 along the SW Atlantic coast. Mar. Pollut Bull., v.60, p.1652-1657, 2010.

HOCKEN, A.G. Post-mortem examination of penguins. DOC Science Internal Series 65. Department of Conservation, Wellington, 2002. 25 .
JAENISCH, F.R.; CUCCHI, V.; BITENCOURT, G. et al. Histopatologia em pulmões e corações de frangos suplementados com oxigênio durante a fase de incubação. Cienc. Rural, v.35, p.633638, 2005.

KEYMER, I.F.; MALCOLM, H.M.; HUNT, A.; HORSLEY, D.T. Health evaluation of penguins (Sphenisciformes) following mortality in the Falklands (South Atlantic). Dis. Aquat. Organ., v.45, p.159-169, 2001

LIPSCOMB, T.P.; HARRIS, R.K.; MOELLER, R.B. et al. Histopathologic Lesions in Sea Otters Exposed to Crude Oil. Vet. Patho. vol 30, p.1-11, 1993.

LUMEIJ, J. T. AND B. W. RITCHIE. Cardiology. In RITCHIE, B. W.; G. J. HARRISON AND L. R. HARRISON(eds), Avian Medicine: Principles, and Applications, Wingers Publishing Inc., Lake Worth.1994 p. 695-722.

PÜTZ, K.; SCHIAVINI, A.; REY, A.R.; LÜTHI, B.H. Winter migration of magellanic penguins (Spheniscus magellanicus) from the southernmost distributional range. Mar. Biol., v.152, p.1227-1235, 2007.

ROME, E.S.; AMMERMAN, S. Medical Complications of Eating Disorders: An Update. J. Adolescent Health, v.33, p. 418-426, 2003.

ROOS, A.L. Pinguins-de-magalhães (Spheniscus magellanicus) no Nordeste: migrantes ou errantes? Boletim Eletrônico do CEMAVE Ano II - $\mathrm{n}^{\mathbf{o}} 2,1,2008$.

SICK, H. Ornitologia Brasileira. Rio de Janeiro: Nova Fronteira, 1997. 912p.

XAVIER, M.O.; SOARES, M.P.; MEINERZ, A.R.M. et al. Aspergillosis: a limiting factor during recovery of captive Magellanic penguins. Braz. J. Microbiol., v.38, p.480-484, 2007. 